\title{
Curriculum reform in Turkish teacher education: Attitudes of teacher educators towards change in an EU candidate nation
}

\author{
Gary M. Grossman ${ }^{\mathrm{a}}$, Pinar E. Onkol ${ }^{\mathrm{b}}$, Margaret Sands ${ }^{\mathrm{c}, *}$ \\ ${ }^{a}$ Arizona State University, USA \\ ${ }^{\mathrm{b}}$ Middle East Technical University, Turkey \\ ${ }^{\mathrm{c}}$ Bilkent University, Director, Graduate School of Education, Bilkent 06800, Ankara, Turkey
}

\begin{abstract}
Educational development is one way through which Turkey enhances progress towards its social goals and prepares itself for European Union membership. A major effort to upgrade the Turkish educational system was made through a multi-phased comprehensive reform of the sector introduced during the 1990s. One part of this reform, perhaps most crucial to the long-term effectiveness of other developments in education, was a transformation of the approach to teacher education. This paper utilizes recently conducted research to assess the nature and extent of that reform as well as identifying the factors which enhanced its effectiveness.
\end{abstract}

(C) 2006 Elsevier Ltd. All rights reserved.

Keywords: Teacher education; Educational policy; Teacher educator education; Educational reform; Turkey

\section{Introduction}

The World Bank-funded national education development project (NEDP): Pre-service Teacher Education component was implemented in Turkey between 1994 and 1999 by the Turkish Higher Education Council (HEC). The technical assistance was provided by the British Council and Arizona State University. The aim was to improve the preservice education of teachers in Turkey. Towards the end of the project, the HEC instituted a parallel reform: the restructuring of the faculties of education. Restructuring involved instituting new pro-

\footnotetext{
*Corresponding author.

E-mail addresses: Gary.Grossman@asu.edu (G.M. Grossman), ponkol@metu.edu.tr (P.E. Onkol), msands@bilkent.edu.tr (M. Sands).
}

grammes and courses, changing the composition of departments, and revising the content of courses.

In 2003-2004, four years after the end of the project and the restructuring, a major study of their effects was conducted under the sponsorship of the Fulbright Commission for Educational Exchange between the United States and Turkey. One portion of the study consisted of an evaluation of the project's teacher education curriculum reform. The study measured a representative national sample of Turkish teacher educators and educational leaders, constituting one of the largest surveys of the teacher educator community in Turkish history. It considered their levels of acceptance together with their use of project ideas and materials, and their attitudes to the changes needed in teacher education as Turkey aims towards EU membership. 
This paper examines the effectiveness, from the perspectives of teacher educators, of these recent teacher education reforms in Turkey. It specifically looks at the efforts to change curricula and accreditation criteria in faculties of education across Turkey, and examines the theoretical implications for the change in teacher education in an institutional context. Attitude differences between Turkish teacher educators in terms of experience, rank, and length of time spent abroad are also considered, factors which the research found to be of relevance in separating attitudes towards the reform and the future of Turkish teacher education. Finally, the paper addresses issues which may be useful for other countries with similar developmental goals, both inside and outside the EU.

\section{Previous teacher education reforms in Turkey}

Like all countries, Turkey is seeking to improve its schools to better respond to higher social and economic expectations. Indeed, Turkey is faced with the same set of complex contemporary demands characteristic of societies responding to changing social, economic, and political circumstances (OECD, 2005a; Kallos, 2003). However, Turkey differs markedly from many other countries in terms of the degree to which education is perceived to be a priority. Since the foundation of the Turkish Republic in 1923, educational development has been regarded as the most important factor in reaching the level of the civilized European countries. As Mango (2004, p. 157) states, “(e)ducation was the means by which the country would catch up with contemporary civilization". The Turkish emphasis on the importance of education is, therefore, one of the bedrock principles of the Republic and, throughout Republican history, education has been a high priority. Education reform has been an ongoing process and some of Turkey's results have been impressive. These issues have been treated extensively elsewhere, notably with regard to the history of Turkish education reform (Mango, 2004; Sakaoğlu, 2003); dramatic increases in literacy among young people (State Institute of Statistics, 2005); rapid increase in the number of publiclyfunded universities (Dundar and Lewis, 1999); rapid increase in the number of schools and the enrolment rate of students (MONE, 2002); expenditure in education (UNDP, 2005); the restructuring of teacher training programs (Şimşek and Yıldırım, 2001); and the reforms driven by Turkey's possible entry into the European Union (Grossman and Onkol, 2006; World Bank, 2005). On the other hand, the true value of change in the education sector takes many years to appear and, moreover, the results of such reforms in the past have been uneven in certain areas. For example, Dundar and Lewis (1999) suggest that implementation of many well-intended reforms has been inefficient, and Şimşek and Yildırım (2001) indicate that the process of restructuring university-level faculties of education is incomplete.

Meanwhile, the priority which is given to education in Turkey has intensified in the context of its recent EU candidacy (World Bank, 2005). Thus, the process of change itself is worthy of exploration. A number of issues present themselves within this dynamic environment and Turkey's attempt not only to reform but to do so quickly is and will remain a topic of importance. Turkey is simultaneously reforming and implementing reform.

This paper examines one such issue, the specific impact of a dramatic effort to reform the way teachers are trained. Such teachers, newly trained under the changed system, reach the field as products of a totally different approach to teacher education in Turkey. Indeed, acknowledging Goodlad's (2004, p. 167) classic notion that '..able teachers...make an important difference in students' learning,' these new teachers will have new strategies and techniques for their work and more direct participation in decision-making than their predecessors. The OECD report (OECD, 2005b) on attracting and retaining effective teachers points out that the large number of teachers recruited in the expansion phase of 1960-1980 are now retiring, which gives an unparalleled opportunity. The newly qualified teachers in Turkey will be trained by teacher educators who have ushered in the reform. Thus, what teacher educators think about the teaching and learning process is crucial, especially in a time of rapid change. The question of the study described in this paper is how are Turkish educators responding to change as it occurs?

\section{Current teacher education reform: the Turkish NEDP/HEC project}

The World Bank-funded HEC Pre-service Teacher Education project was requested by the Turkish government in 1989, and implemented between 1994 and 1999. The teacher education project was half of the NEDP. The companion part 
was located in the Ministry of National Education (MONE) between 1992-1997, with the purpose of introducing structural reforms in the government. This paper refers to the pre-service component section of the National Education Development Project as NEDP/HEC.

The NEDP/HEC had several dimensions, the first and most important being the development of newly designed teacher education curricula in thirteen subject areas. The purpose of the curriculum reform was to change the focus of Turkish teacher education to give a far greater emphasis on teaching methods. The developmental work involved fifteen experienced teacher educators from the education faculties of Turkey, paired and working full time with, seventeen counterpart teacher educators from the United States, the United Kingdom, and Sweden. The curriculum development also involved in-country training at a series of workshops (see Figs. 1 and 2).

Other aspects of the project included 313 shortand long-term fellowships, ranging from one week to 39 months, the most intensive of which involved 73 Turkish students selected through a competitive process and sent to the United States, United Kingdom, and Germany for masters and doctoral degrees. These students would then return to Turkey to positions within the university teacher education system to lead the development of the new model of Turkish teacher education. The curriculum reform and the fellowships involved 34 faculties of education in Turkey at the start of the NEDP/HEC project in 1995, rising to 42 by its end in 1999. All faculties, including new ones, were included in the project's developmental work. Towards the end of the project, an accreditation process aimed at the eventual certification of teacher preparation faculties in Turkey was developed and piloted in nine faculties of education.

Additionally, the project staff provided administrative support for the Higher Education Council's restructuring of faculties of education and their teacher education programmes. This was a parallel reform which took place at the HEC within the same time frame but having different purposes from the teacher education curriculum reform.

The pre-service teacher education project focused mainly on the methodology of teaching different subject areas, the development of student teaching in elementary and high schools, and on educational studies. Student teacher work in schools had been given low priority in previous pre-service training in Turkey. The curriculum development work of the project aimed to update and improve the teaching methods at primary level in Mathematics, Science,

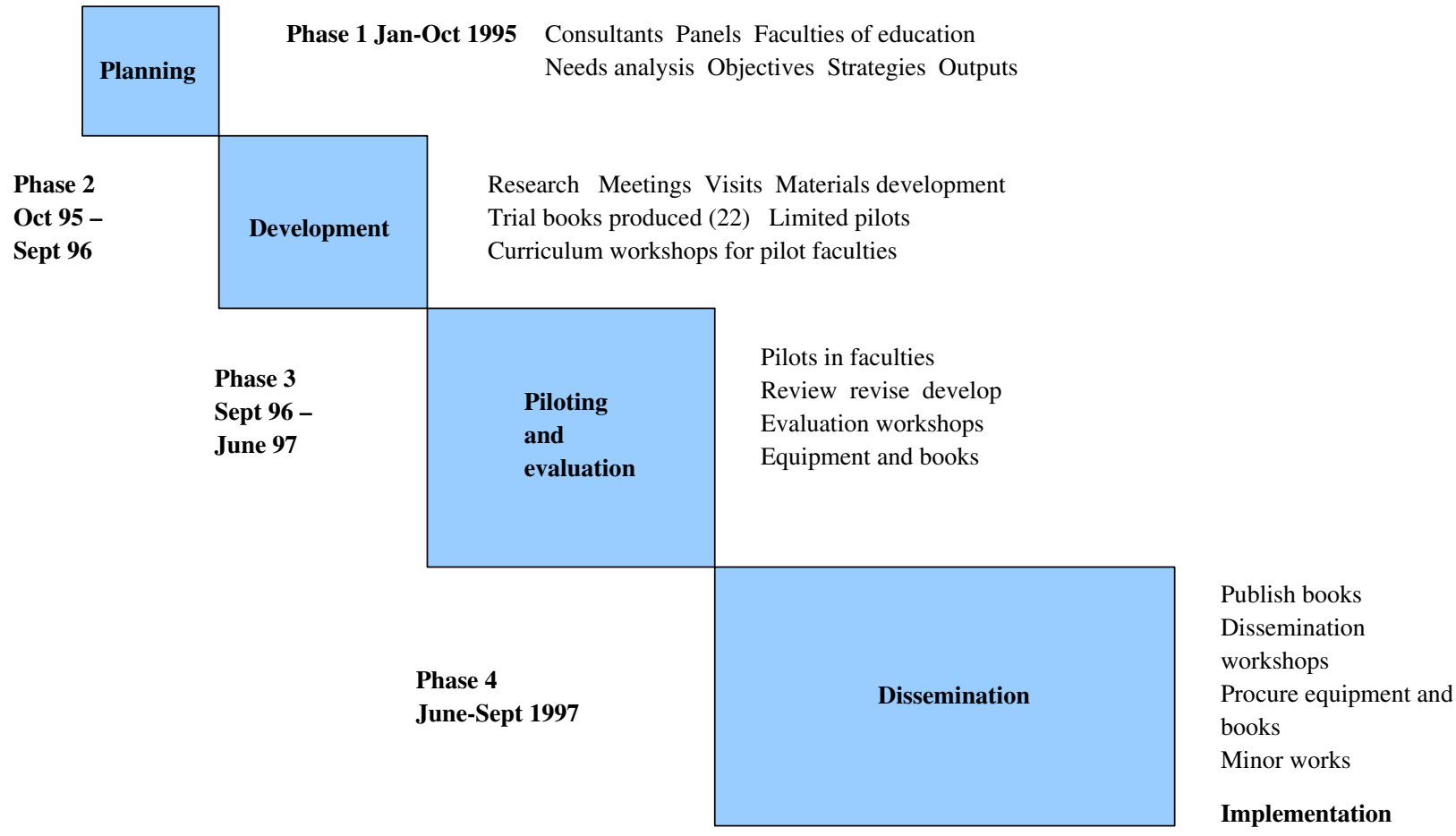

Fig. 1. Curriculum development strand of the project. 


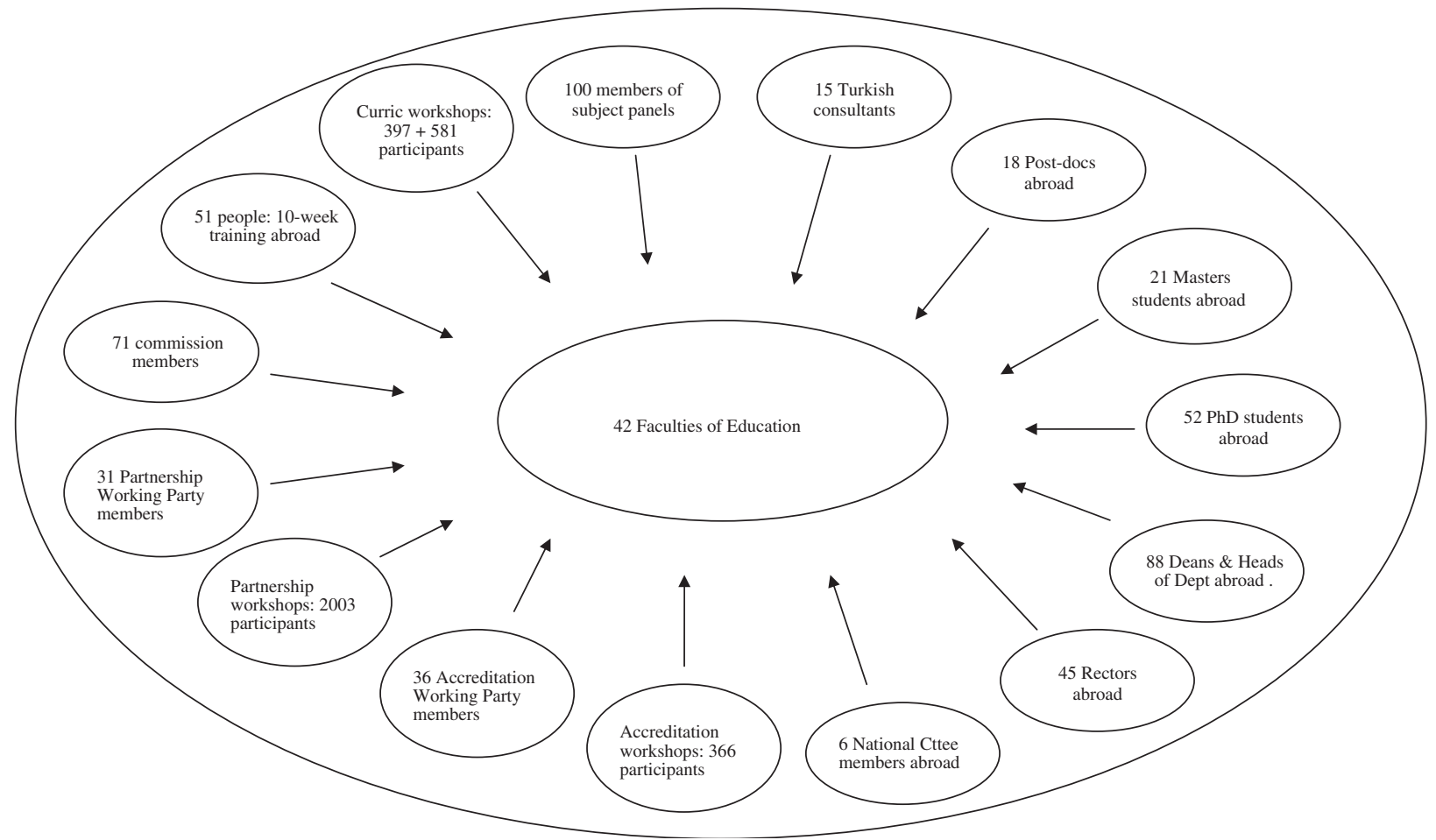

Fig. 2. Groups of people involved with the project.

Social studies, Music and Art, and at secondary level in Mathematics, Biology, Chemistry, Physics, Social science, English, Music, and Art. For each subject area the intention was to provide the following.

- A revised curriculum based on the perceived needs of the users as analyzed by leading teacher educators, who reached a consensus on objectives, content, and implementation.

- A curriculum that incorporated relevant and upto-date ideas, activities, and other material from developments and achievements in teacher education curriculum reform in other countries.

- A student-centred and constructivist approach to student learning.

- Student textbooks with accompanying teacher's guides which embodied the revised curricula, including content, student teaching/learning activities, and instructors' guidelines. Twenty-two such books were produced by the end of phase two of the project for use during pilots of the new curriculum. Instructors could use the books either in their entirety or as a resource.

- A comprehensive system of training courses connected to the new materials.
- Equipment, apparatus, teaching resources, and reference books linked to the developments.

It was a formidable challenge, over a very short time, to change the curriculum and provide tailormade resources for the teachers of some 130,000 undergraduate education students at 42 faculties of education. Even more daunting was the need to change the hearts and minds of those teacher educators. It takes time to change attitudes and behaviour, hardly achievable in the four years of the project implementation. It was recognized, however, that one key to the effectiveness of this reform was precisely the involvement of participants. To this end, a collegial model was combined with the more traditional 'power-coercive' approach. As Havelock and Huberman (1977, p. 256) point out in their major study of educational innovation in countries across the world, the power-coercive strategy has its advantages. "(T)here are strong temptations to follow a power strategy of innovation....among these are the need for co-ordination of effort; the necessity of overcoming inertia; and efficiency". However, dissemination and nation-wide implementation were the long-term aims of the work. Institutionalization is better achieved if more people 
are involved with, and committed to, the work from its inception. From the beginning, the project aimed to bring as many people as possible on board, both within and outside the teacher educator community.

The project began by gathering a critical mass of experienced teacher educators, both Turkish and those from other countries. They worked together, day by day, over a period of time and were involved in decision making with the Project Co-ordination Unit (PCU). The PCU was appointed by the Turkish Government to lead and oversee the development of the project. It reported directly to the Higher Education Council. These educators were as follows.

- Seventeen international consultants from the US, UK, and Sweden and their 15 Turkish counterparts.

- A subject panel of about eight people for each of the 13 subject areas, at primary and secondary levels. The panels were composed of specialists from different faculties of education, chosen to be representative of all education faculties. Their terms of reference were to work with the two consultants per subject area on needs analysis leading to the definition of objectives and content, to contribute to the production of curriculum materials, review and comment on the writing as it progressed, plan and teach training courses, conduct trials of the materials in their own department, and give constructive feedback to the group.

The overall design of the curriculum development strand of the project is shown in Fig. 1.

The plan was to involve as many people as possible in activities that would result in a change in their own teaching practices and provide them with relevant and up-to-date teaching materials including core books, written by the specialists and their panels. The developments would be closely connected with improved institutional facilities, plus the provision to the faculties of education of relevant equipment, apparatus, teaching resources, and reference books, to assist with the implementation of the new curricula. The final aim was to have the new curriculum implemented in all faculties of education.

A major element of the plan was a series of training courses to be given to as many as possible of the university lecturers teaching the curriculum under review. The first workshops were held at the end of the intensive period of work of the central group, in summer 1996, prior to the pilots in many faculties. The aim was to familiarize lecturers in the use of the materials and activities of the new curricula. Then, through the pilot year, these faculties were visited. They gave feedback, had onthe-spot training, and were brought together for a feedback and re-writing workshop two-thirds of the way through the year.

From the start, the project disseminated ideas and materials. At all stages, from start to finish, as many people as possible were included. By the end of the project, after four-and-a-half years, 3881 people had been directly involved at some level, as summarized in Fig. 2.

The ideas generated by the project were disseminated all over Turkey, first by the curriculum books and workshops, later through other project vehicles. From the beginning, strenuous efforts were made to involve faculties of education. In the first nine months, the Project Coordination Unit and the Technical Assistance leader visited almost all faculties and held meetings with the University Rector, the Dean of Education, and all education faculty members. The subject panels were also dissemination mechanisms, as 100 people from around Turkey, some travelling $12 \mathrm{~h}$ each way by bus, met with their consultants every month in the project office. Between meetings, they sounded out, consulted with, and informed their own immediate colleagues.

The curriculum workshops involved 397 people in 1996 alone, preparing and evaluating (1997) the pilot materials. The pilot activities themselves disseminated the curriculum materials to all faculty and students in the subject areas being tested. Monitoring visits from consultants and panel members also promoted the spread of ideas.

The dissemination workshops later in 1997 involved 581 teacher educators using the newly revised and published books. Multiple copies of all books were distributed to all faculties. A copyright waiver allowed further supplies to be photocopied from the originals. The partnership workshops around the country in 1998 used the project's publications on school partnerships and work in schools (Koç et al., 1998; Sands and Özçelik, 1998) to train 2003 academics and schoolteachers as partnership participants.

In 1997, support was given to subject area commissions of 71 people formed by HEC as part of the restructuring of the faculties of education. 
The commissions were set up to revise programs and courses for the newly restructured faculties.

In addition, the project set out to inform and give experience of overseas developments in teacher education to senior personnel in education faculties and at their universities by providing study tours abroad. Thus 88 deans and heads of department, and 51 rectors and National Committee members were numbered among the international fellowships. Further, the graduate students who had received project fellowships to pursue their doctoral or master's studies abroad returned to Turkey to give twice that number of years of service to the faculty to which they had been assigned. These students, educated abroad in the UK, US and Germany, are now located all over the country, from Van to Istanbul, from Hatay to Edirne. They serve as a powerful thrust in the further and future dissemination of project ideas and practices.

As a result of the staff development from beginning to end of the project, a large number of informed people (3881) were able to take forward the ideas of the project. For some of them, experience with the project was slight, and could hardly be expected to produce a lasting effect. But for others the activity was intensive and could be assumed to have a significant influence. However, although there were many activities and involvements, there were still many people in the faculties of education who did not directly participate in the work of the project. The Fulbright study investigated the key question of the effect of this reform of pre-service teacher education.

\section{The Fulbright study: methodology}

The Fulbright study of Turkish teacher educators, conducted in 2003-2004, featured a three-part survey of full-time university academics (known in Turkey as assistant professors, associate professors, and full professors) employed in the education faculties of 54 state universities in Turkey. The initial contact was a selection process through which approximately one-third of the qualifying university lecturers were randomly selected for the sample $(N=457) .170$ of them agreed to take part in the study. This sample was given an internet-based survey instrument in Turkish with 82 questions including both scaled response and open-ended questions.

From this respondent base, a random selection of 38 teacher educators received a follow-up telephone interview for in-depth discussion of teacher education issues. Finally, seven teacher education leaders were surveyed to examine the views of decisionmakers on these issues. Generally, the data collected from the survey were analyzed through the use of descriptive and inferential statistical analysis. The data from the interviews with teacher educators were analyzed using qualitative techniques.

The questionnaire developed was subject to expert review and given to five teacher educators, from one of the leading teacher education institutions in Ankara, who had been actively involved in 1997 in the developmental changes. Changes were made as necessary to the online questionnaire according to their feedback. The academic department from which they were drawn was subsequently exempted from the survey sample.

\section{Characteristics of teacher educators who responded to the online survey}

The teacher educators who responded to the online survey $(N=170)$ are identified as shown in Table 1.

Through an ex post facto analysis of data, the sample was seen to be representative of the Turkish teacher education community by academic rank, geographic dispersion, and university faculty size, as the percentages in all areas were roughly parallel to their presence overall. The survey was able to discern, incidentally, a unique aspect of Turkish academic life, namely the high degree of employment stability found in Turkish universities. Far more often than is the case in other countries, young people working as graduate assistants in Turkey remain with the same university as they are promoted in their academic career. Several universities are now addressing this 'inbreeding' phenomenon, but it is still normal to find relatively young academics who have worked for ten years or more in the same university. While the NEDP/HEC project attempted to assist cross movement to some extent by assigning fellows returning from degree courses abroad to the newer teacher education faculties, this condition will continue to characterize Turkish academic life for some time to come.

\section{Data analysis and discussion}

Of the 82 questions in the general survey of the Fulbright research, 34 dealt directly with the NEDP/HEC project. The remainder dealt with 
accreditation and HEC's restructuring (22 questions); general issues in Turkish education (12); and demographic criteria (14). The entire sample of 170 Turkish teacher educators responded to the core of the survey in each area. Depending on their answers, they were asked more detailed questions. Some, with little knowledge and/or experience of the subject under investigation, were automatically advanced to another section by the internet-based survey. Only the most knowledgeable respondents answered all 82 items.

With regard to the most general aspects of reform, Table 2 shows that the respondents thought that need for change in Turkish education was overwhelming.

In this context of a strongly felt need for improvement, the survey asked about efforts to improve education, particularly projects funded by the World Bank, the United Nations, the European Union, and others. The respondents were asked their opinions regarding the effectiveness of such projects, with the results as shown in Table 3 .

Table 1

Characteristics of Turkish teacher educators

- From 54 public universities

- Seven geographical regions

1. Marmara (Istanbul area): $18.3 \%(N=32)$

2. Aegean (Izmir area): $13.6 \%(N=23)$

3. Mediterranean (Antalya area): $5.3 \%(N=9)$

4. Southeastern Anatolia (Diyarbakır area): $1.8 \%(N=3)$

5. Central Anatolia (Ankara-Kayseri area): $36.7 \%(N=62)$

6. Eastern Anatolia (Van area): $8.9 \%(N=15)$

7. Black Sea (Samsun-Trabzon area): $15.4 \%(N=26)$

- Age range: $28-65($ mean $=42.9, \mathrm{SD}=8.53)$

- Full professors: $19.4 \%(N=33)$

- Associate professors: $10.6 \%(N=18)$

- Assistant professors: $59.4 \%(N=101)$

- Other positions: $10.6 \%(N=18)$

- Duration of position title for 6 years or fewer: $61.8 \%$ $(N=105)$

- Duration of position title for more than 6 years: $38.2 \%$ $(N=65)$

- Employed at same university more than 12 years: $43.5 \%$ $(N=74)$

- Employed at same university 6-12 years: $32.4 \%(N=55)$

- Employed at same university fewer than 6 years: $24.1 \%$ $(N=41)$

- Speak at least one foreign language fluently: $53.5 \%(N=90)$. Of these:

1. English: $75.6 \%(N=68)$

2. German: $11.1 \%(N=10)$

3. French: $5.6 \%(N=5)$

- Speak two or more foreign languages fluently: $7.7 \%(N=13)$
Table 2

Which of the following best reflects your position regarding the general state of Turkish education today? $(M=3.56, S D=0.6)$

\begin{tabular}{lcc}
\hline & $N$ & $\%$ \\
\hline $\begin{array}{l}\text { 1. It is fulfilling its function very well and } \\
\text { needs no improvement }\end{array}$ & 0 & 0.0 \\
$\begin{array}{l}\text { 2. It is fulfilling its function and needs slight } \\
\text { improvement }\end{array}$ & 10 & 5.9 \\
$\begin{array}{l}\text { 3. It is fulfilling its function and needs some } \\
\text { improvement }\end{array}$ & 54 & 31.8 \\
$\begin{array}{l}\text { 4. It is failing to fulfil its function and needs } \\
\text { profound improvement }\end{array}$ & 106 & 62.3 \\
Total & & \\
\hline
\end{tabular}

Table 3

In general, how valuable have these projects been in improving education? $(M=3.21, S D=0.657)$

\begin{tabular}{|c|c|c|}
\hline & $N$ & $\%$ \\
\hline 1. Without any value. Nothing has improved. & 7 & 4.1 \\
\hline $\begin{array}{l}\text { 2. Somewhat less than valuable. A few things } \\
\text { have improved. }\end{array}$ & 78 & 45.9 \\
\hline 3. Neither valuable nor without value. & 30 & 17.6 \\
\hline $\begin{array}{l}\text { 4. Somewhat valuable. Some things have } \\
\text { improved. }\end{array}$ & 53 & 31.2 \\
\hline $\begin{array}{l}\text { 5. Highly valuable. Many things have } \\
\text { improved. }\end{array}$ & 2 & 1.2 \\
\hline Total & 170 & 100.0 \\
\hline
\end{tabular}

With a large number of the respondents believing that the projects had either little or no value, the survey asked why these efforts might not have been as successful as they should have been. Table 4 shows the responses.

The data in Table 4 demonstrate some cynicism about educational reform, with nearly three-quarters of the respondents thinking that education in Turkey is 'too political'. It is in this environment that the NEDP/HEC project with its twin power-coercive/stakeholder-participatory strategy was placed.

Table 5 shows data regarding the subjective state of respondent knowledge about reform efforts, indicating familiarity with developments. It is followed by Table 6 which shows that most knew about the NEDP.

Based on the data therefore, respondents considered themselves well informed about recent activity in the general area of educational reform in Turkey, and in particular of the multi-dimensional NEDP. Of the 157 who said that they had 
Table 4

Which three items would you say contribute most to this situation? (Reasons given to explain why efforts at education reform may not have been as successful as they could have been.) $(N=170)$

\begin{tabular}{lrr}
\hline & $N$ & $N$ \\
\hline 1. Turkey has too few resources to devote to serious education reform & 45 & 26.5 \\
2. Educational leaders are not sincere about wanting to reform education & 78 & 45.9 \\
3. Government was unstable, unable to maintain education reform programs & 2 & 1.2 \\
4. There has been too much religious influence in education & 7.1 \\
5. Educators in Turkey do not know enough to improve education & 46 & 27.1 \\
6. Education in Turkey is too political & 124 & 24 \\
7. There has been too much foreign influence in Turkish education & 11 \\
8. The World Bank and IMF have too much control over Turkish education & 49.1 \\
9. Efforts to reform Turkish education have been too limited in scope & 6.5 \\
10. The Turkish people do not support education & 28.8 \\
11. Other reasons (respondent identified) & 6.5 & 71 \\
\hline
\end{tabular}

Table 5

How familiar are you about recent attempts to improve Turkish teacher education? $(M=1.48, S D=0.72)$

\begin{tabular}{lrr}
\hline & $N$ & $\%$ \\
\hline 1. Very familiar & 107 & 62.9 \\
2. Somewhat familiar & 50 & 29.4 \\
3. Neither familiar nor unfamiliar & 8 & 4.7 \\
4. Somewhat unfamiliar & 5 & 2.9 \\
5. Very unfamiliar & 0 & 0.0 \\
Total & 170 & 100.0 \\
\hline
\end{tabular}

Table 6

Have you heard of the World Bank-supported National Education Development Project (NEDP)? $(M=1.08$, $S D=0.267)$

\begin{tabular}{lrr}
\hline & $N$ & $\%$ \\
\hline 1. Yes & 157 & 92.4 \\
2. No & 13 & 7.6 \\
Total & 170 & 100.0 \\
\hline
\end{tabular}

heard of the NEDP/HEC, $69.4 \%$ reported that they knew in-service training was part of the project; $96.2 \%$ knew that curriculum development was included; and $87.3 \%$ knew that training abroad was included.

Of these respondents, $44.6 \%$ reported that they themselves had also participated in some way in the project, confirming the goal of the curriculum development portion of the NEDP/HEC for broadly based involvement in the curriculum reform effort. Thus, the data suggest that the respondents believed that they knew the project and this was
Table 7

In your opinion, did the NEDP meet its overall goals? $(M=1.83$, $S D=0.379)$

\begin{tabular}{lrr}
\hline & \multicolumn{1}{c}{$N$} & \multicolumn{1}{c}{$\%$} \\
\hline 1. Yes & 27 & 17.2 \\
2. No & 130 & 82.8 \\
Total & 157 & 100.0 \\
\hline
\end{tabular}

Table 8

How successful overall would you say the NEDP was? $(M=1.83, S D=0.738)$

\begin{tabular}{lrr}
\hline & \multicolumn{1}{c}{$N$} & \multicolumn{1}{c}{$\%$} \\
\hline 1. Very successful & 0 & 0.0 \\
2. Somewhat successful & 27 & 17.2 \\
3. Neither successful nor unsuccessful & 79 & 50.3 \\
4. Somewhat unsuccessful & 47 & 29.9 \\
5. Not successful at all & 4 & 2.5 \\
Total & 157 & 100.0 \\
\hline
\end{tabular}

confirmed in open-ended questioning, in which they correctly identified some of its major aims.

Regarding success, the survey asked whether the project met its goals and the extent to which it was successful. Tables 7 and 8 report these results.

In an open-ended follow-up question, respondents who regarded the project as successful reported that it was an important attempt to improve the educational system; that pre-service curricula were changed and improved; and that it had the effect of standardizing teacher preparation across all universities. However, the clear trend of 
the data suggests that the overwhelming response was negative. In this regard, respondents reported that it failed to take cultural/social distinctions into account; that there was a lack of physical and technological resources; and that the project did not take account of the needs of all teacher educators and universities.

The NEDP took in many aspects of two major agencies of government, over the eight years of the whole project: the Ministry of National Education and the Higher Education Council. The survey identified particular dimensions of the NEDP and examined whether differences existed in relation to the parts of the project as compared to the response to the whole. This study is principally concerned with the pre-service teacher education curriculum, the NEDP/HEC component. Table 9 displays the data.

Clearly, the curriculum development portion of the NEDP/HEC does markedly better than the project overall $(46.8 \%$ vs. $17.2 \%)$. It exceeds the performance of the in-service training aspects of the project which gave $32.9 \%$ as 'Successful', and is similar to the Fellowship Training portion with $51.1 \%$ 'Successful', which was a major part of the pre-service dimension.

The survey explored the linkages between attitudes towards the curriculum development part of the NEDP/HEC and awareness of and usage of the materials. The data are reported in Tables 10-12.

Taken as a whole, the data present something of a paradox. With regard to the curriculum materials themselves, they are apparently generally available; over $80 \%$ of the sample acknowledged their presence, in whole or in part, at their university. Moreover, they are or have been used by more than $70 \%$ of the sample. Further, more than $90 \%$ of these regard them as being 'somewhat' to 'very' useful. However, more than half of the sample regards the reform in curriculum development as 'unsuccessful'.

Table 9

With particular regard to the pre-service teacher education curriculum development portion of the NEDP, would you say it was successful or unsuccessful? $(M=1.53, S D=0.502)$

\begin{tabular}{lcr}
\hline & $N$ & \multicolumn{1}{c}{$\%$} \\
\hline 1. Successful & 36 & 46.8 \\
2. Unsuccessful & 41 & 53.2 \\
Total & 77 & 100.0 \\
\hline
\end{tabular}

Table 10

The pre-service teacher education curriculum development portion of the NEDP/HEC produced curriculum books and other materials, and provided curriculum-specific equipment to universities. Have you ever seen any of these materials at your university? $(M=1.93, S D=0.636)$

\begin{tabular}{lcc}
\hline & $N$ & $\%$ \\
\hline $\begin{array}{l}\text { 1. Yes, I have seen all of these products at my } \\
\text { university }\end{array}$ & 36 & 24.0 \\
$\begin{array}{l}\text { 2. Yes, but I have seen only some of them at } \\
\text { my university }\end{array}$ & 89 & 59.3 \\
$\begin{array}{l}\text { 3. No, I have seen none of them at my } \\
\text { university }\end{array}$ & 25 & 16.7 \\
\begin{tabular}{l} 
Total \\
\hline
\end{tabular} & 150 & 100.0 \\
\hline
\end{tabular}

Table 11

Do you use or have you used in the past any of the new teacher training materials developed by the NEDP/HEC in your teaching? $(M=2.14, S D=1.188)$

\begin{tabular}{lrr}
\hline & $N$ & $\%$ \\
\hline 1. Yes, I currently use these materials & 56 & 56.0 \\
2. Yes, I used to use these materials, but no & 15 & 15.0 \\
longer do so & & \\
3. No, I have never used these materials & 29 & 29.0 \\
Total & 100 & 100.0 \\
\hline
\end{tabular}

Table 12

Which one of the following statements best reflects your position regarding these new teacher training curriculum materials? $(M=1.89, S D=0.522)$

\begin{tabular}{lrr}
\hline & $N$ & $\%$ \\
\hline 1. I have found them to be very useful & 14 & 19.7 \\
2. I have found them to be somewhat useful & 51 & 71.8 \\
3. I have found them to be of little use & 6 & 8.5 \\
4. I have found them to be of no use & 0 & 0.0 \\
Total & 71 & 100.0 \\
\hline
\end{tabular}

This sense of paradox is heightened by examining the data from the follow-up survey, in which 38 respondents, randomly selected from the 170 represented in the general survey, were probed in depth about their attitudes through open-ended items. In an examination of the extent to which any policy or action represented the "most important reform' of the past decade, $35(92 \%)$ reported that there had been one. Of these, more than half spontaneously self-reported some aspect of the 
NEDP/HEC-related activity (curriculum development, fellowship training, accreditation, or mentioned the parallel restructuring of education faculties). What many found valuable as an outcome of the project was the connection between theory and practice; the standardization of curricula across the country; and an improvement in the quality of the training itself, all very specific aims of the NEDP/HEC project. Twenty-six of the 38 $(68 \%)$ in the follow-up regarded NEDP/HEC as 'an important reform', and mentioned that the project had accomplished many of its aims.

The data show that the project was highly regarded. But how could it also be considered by those same people to be 'unsuccessful'? A closer examination of the data suggests possible explanations. One may reside in the hypothesis that respondent attitudes are a function of participation or awareness of the project. Using Pearson's product-moment correlation in a matrix format, zero-order data are shown in Table 13.

The data in Table 13 show that 'Participation', 'Used', and the presence of the materials at the respondent's university 'Seen', have significant relationships to respondent views as to the 'Success' of the curriculum development work of the project. Still, these are quite moderate in magnitude and do not themselves adequately explain the paradox identified. Possibly, inasmuch as there is some significant inter-correlation between variables other than 'Success', the bivariate measure may suppress the magnitude to which these variables work together to explain success. Accordingly, those variables significantly linked to success ('Participation', 'Used', and 'Seen') were included in a multiple correlation design. On a stepwise regression analysis of the variables entering the equation, only 'Parti- cipation' remained as a significant factor, clearly suggesting that it was replacing the effects of the others in predicting the differential in 'Success'. While worth noting, the data show that the $R$-value of .339 indicates that $11.5 \%$ of the variance is explained. Thus, this seems too modest an explanation to this question.

A second possibility is that the willingness of some in the sample to call the curriculum development work of the project 'Unsuccessful', despite strong evidence of its regard elsewhere, represents a resistance to change. Perhaps change is embraced to a greater degree by newer members of the Turkish teacher education community, but viewed as a threat by senior colleagues? The curriculum development work involved the use of new models adapted from abroad: could training abroad be considered a factor, as those who had studied abroad were necessarily exposed to alternative teacher education models? Survey data provide a test for this, as shown in Table 14.

While certain levels of correlation emerge between potential predictor variables, the data in no way suggest that these predictors are linked with the variability in 'Success'. Indeed, no single factor suggests that resistance to change might be the cause of differentiation in response.

Of the factors examined thus far, only 'Participation' remains as a potential link with the dependent variable and it, by itself, is neither sufficiently illuminating nor powerful enough to constitute an explanation. However, it may lead to a more thorough analysis of the implementation strategy undertaken by the Higher Education Council with regard to the project. As will be recalled, the project team undertook a dual power-coercive/stakeholder participatory approach. The question that emerges

Table 13

Zero-order matrices-correlates of 'Success'

\begin{tabular}{|c|c|c|c|c|c|c|}
\hline & Success & Aware & Participation & Used & Seen & Value \\
\hline Success & - & 0.000 & 0.280 & 0.280 & 0.344 & 0.101 \\
\hline Aware & 0.000 & - & 0.179 & -0.079 & 0.131 & 0.046 \\
\hline Participation & 0.280 & 0.179 & - & 0.107 & 0.362 & 0.033 \\
\hline Used & 0.280 & -0.079 & 0.107 & - & 0.316 & 0.379 \\
\hline Seen & 0.344 & 0.131 & 0.362 & 316 & - & 0.206 \\
\hline Value & 0.101 & 0.046 & 0.033 & 0.379 & 0.206 & - \\
\hline
\end{tabular}

Significance at the $p<0.05$ level shown in bold.

Notes: NEDP Curriculum Development Success = Success, Having heard of the NEDP Curriculum Development = Aware, Participation in NEDP = Participation, Use of curriculum materials = Used, Having seen the materials = Seen, Usefulness of curriculum materials $=$ Value. 
Table 14

Zero-order matrices-experience and 'Success'

\begin{tabular}{lrrrrrr}
\hline & Success & Job & Tenure & Service & Abroad & \multicolumn{1}{l}{ Age } \\
\hline Success & - & 0.032 & 0.047 & -0.023 & 0.151 & 0.009 \\
Job & 0.032 & - & $-\mathbf{0 . 1 9 5}$ & $-\mathbf{0 . 3 0 3}$ & $\mathbf{0 . 3 9 6}$ & $-\mathbf{0 . 5 8 4}$ \\
Tenure & 0.047 & $-\mathbf{0 . 1 9 5}$ & - & $\mathbf{0 . 3 8 0}$ & -0.145 & $\mathbf{0 . 5 7 0}$ \\
Service & -0.023 & $\mathbf{- 0 . 3 0 3}$ & $\mathbf{0 . 3 8 0}$ & - & $\mathbf{0 . 2 7 3}$ & $\mathbf{0 . 4 5 0}$ \\
Abroad & 0.151 & $\mathbf{0 . 3 9 6}$ & $-\mathbf{0 . 1 4 5}$ & $\mathbf{0 . 2 7 3}$ & - & -0.249 \\
Age & 0.009 & $\mathbf{- 0 . 5 8 4}$ & $\mathbf{0 . 5 7 0}$ & $\mathbf{0 . 4 5 0}$ & -0.249 & - \\
\hline
\end{tabular}

Significant at the $p<0.05$ level shown in bold.Notes: NEDP Curriculum Development Success $=$ Success, Academic Job Title: Professor-Graduate Assistant $=$ Job, Length of service in position $=$ Tenure, Years of service in university $=$ Service, Training abroad $=$ Abroad, Age at last birthday $=$ Age.

is whether the perceived value of the project is less a function of the merit of its products than it is participation in the project itself. Put another way, mere satisfaction with the outcomes of reform may matter less in terms of its ultimate acceptance than does the sense of having had a role in crafting change.

This perspective would be highly consistent with the perspective offered years ago by Havelock and Huberman (1977) and is relevant to the 'Central governance vs. local autonomy' dichotomy offered more recently by Garm and Karlsen (2004), although the principal focus of the latter was seen in the context of broader processes of globalization.

Essentially, the argument proposed here is that the strategic dualism of the implementation process created the paradox found in the data between satisfaction with many of the outcomes of the NEDP and dissatisfaction with the enterprise as a 'project'. Indeed, the qualitative data in the followup study points repeatedly to the top-down nature of decision-making and 'lack of consultation' as a reason why the success of the project was limited; or the top-down approach is offered as an inappropriate way to execute a project. Despite the fact that literally thousands of people in the Turkish education community were involved in all aspects of project implementation, this argument seems to hold. Namely, the reform was imposed from above, even though the implementation involved many people.

To the extent that any one person participated, we might expect attitude differences not only about the curriculum change, but also other aspects of the project, perhaps even with regard to more general issues in educational reform. Moreover, if participation itself were such a key factor, it should be seen to be relatively uncorrelated with other variables, either those of a more structural nature or those pertaining to attitudes involving issues other than the project. The data from the survey can shed some light on this question. The survey variable 'Participation' was tested against a series of education reform-related variables. Table 15 shows the data.

While the correlation strength of 'Participation' as a predictor is not overwhelming, this is by no means the most important finding from the data in Table 15. Rather, it is the consistency with which 'Participation', acting alone, predicts attitude differences in almost all cases with regard to NEDP matters, but also relatively improves the prediction in more general education reform areas. This finding about the centrality of participation is underscored by a related point, one of the logical extensions of the strategy employed in project implementation.

It was assumed that those who participated in the project would have a seeding effect on their home department and faculty. It was thought that support for project efforts would be enhanced in the entire academic unit if some colleagues participated in project activities. This turns out not to have been the case. A different item which measured the extent to which teacher educators knew of colleagues who participated was compared to the whole list of attitudes separately given in Table 15 . In only two circumstances of the former (Awareness of training

Table 15

'Participation' in the NEDP and view of education reform efforts

\begin{tabular}{lc}
\hline Factors & $r$ value \\
\hline Participation and: & $\mathbf{0 . 2 2 5}$ \\
Value of projects to reform education & $\mathbf{0 . 1 6 4}$ \\
Familiarity with recent efforts to improve & \\
education & $\mathbf{0 . 2 0 6}$ \\
Awareness of teacher in-service in NEDP & $\mathbf{0 . 1 7 9}$ \\
Awareness of teacher pre-service in NEDP & $\mathbf{0 . 3 4 3}$ \\
Awareness of training abroad & $\mathbf{0 . 3 3 8}$ \\
Belief that NEDP met its goals & $\mathbf{0 . 3 2 2}$ \\
Belief that NEDP was a success & 0.193 \\
Belief that NEDP in-service was a success & $\mathbf{0 . 2 8 0}$ \\
Belief that NEDP pre-service was a success & $\mathbf{0 . 3 6 7}$ \\
Belief that NEDP foreign training was a success & $\mathbf{0 . 3 6 2}$ \\
Having seen NEDP materials & $\mathbf{0 . 1 8 5}$ \\
Having used NEDP materials & 0.033 \\
Utility of NEDP materials & $\mathbf{0 . 3 3 0}$ \\
View of quality of NEDP implementation & $\mathbf{0 . 3 3 4}$ \\
View that HEC has helped make improvements in & \\
teacher education & \\
\hline
\end{tabular}

$p<.05$ in bold. 
Table 16

Participation in the NEDP and structural/demographic factors

\begin{tabular}{lr}
\hline Factors & $r$ value \\
\hline Participation and: & \\
Job title & -0.111 \\
Duration of position & 0.074 \\
Tenure at university & -0.103 \\
Going abroad for training & 0.122 \\
Age & 0.121 \\
Region of residence & -0.105 \\
\hline
\end{tabular}

$p<.05$ in bold.

abroad $r=.335$; and belief that NEDP met its goals $r=.208)$ did the tested relationship reach significance. These are exceptions which reinforce the general observation that it was participation in the project alone which made an attitude difference in the Turkish teacher education community.

Finally, the single dimension of participation as a differentiating factor received its strongest support by its lack of correlation with any other potential causal factor. Table 16 illustrates this finding.

Based on the data, it can be said with some confidence that the single most important factor in separating attitude differences toward the Higher Education Council's implementation of its NEDP is the participation of teacher educators in the process. However, the general fact that participation occurred in project implementation was insufficient by itself to offset concerns about the top-down nature of the reform effort in the teacher education community. Nonetheless, participation had a positive effect on a person's view of reform, reducing the power-coercive aspect especially with regard to the specific reform in question. Very importantly, the evidence points to the mediating effect of a participatory partnership with the process of educational reform in general.

\section{Summary and conclusion}

This paper has considered one important educational reform which has been perceived as key in facilitating progress in other developments in the education sector, namely change in teacher education.

Turkey has been generally acknowledged for its achievements in educational reform over the past three decades, times in which political instability plagued its efforts in many areas (World Bank, 2005). In the years since 1982, educational reform has particularly re-emerged as a major priority for Turkey's national attention. The NEDP, initiated by the Government of Turkey and in effect between 1992 and 1999, was an important part of this transformation, redefining much of the scope of Turkish education. Within the project, teacher training was targeted for change and development and, by all measures, was successful. Much was changed in the latter half of the 1990s regarding teacher education in Turkey and the benefits will continue to be felt for many years to come. The key finding of this paper, namely that teacher educator participation was important in maintaining and institutionalizing the changes made by the NEDP, is worthy of attention. While 'efficiency' of a project may be improved by decision-making at the top, the sustainability of project accomplishments clearly requires the full participation of those concerned.

\section{References}

Dundar, H., Lewis, D., 1999. Equity, quality, and efficiency: effects of reform in Turkish higher education. Higher Education Policy 12, 343-346.

Garm, N., Karlsen, G., 2004. Teacher education reform in Europe: The case of Norway; trends and tensions in a global perspective. Teaching and Teacher Education 20, 731-744.

Goodlad, J.I., 2004. A Place Called School, 20th Anniversary ed. McGraw-Hill, New York.

Grossman, G., Onkol, P., 2006. Towards the Europeanization of Turkish teacher education: education reform and professional development in a new context. In: Terzis, N.P. (Ed.), Lifelong Learning in the Balkans. Publishing House Kyriakidis Brothers S.A., Thessaloniki, Greece, pp. 337-357.

Havelock, R.G., Huberman, A.M., 1977. Solving educational problems: the theory and reality of innovation in developing countries. UNESCO, Paris, France.

Kallos, D., 2003. Teachers and teacher education in Sweden: recent developments. Paper presented at meetings organized by Centro Interdipartmentale di Richeche Educative. University of Bologna [On-line]. Available at 〈http://ntee.umu.se/archive/bologna2003.pdf $\rangle$. Access date: August 12, 2005.

Koç, S., Ergezen, S., Ayas, A., Baki, A., Çepni, S., Kıncal, R., et al., 1998. Faculty-school partnership. YÖK, Ankara.

Mango, A., 2004. The Turks Today. Overlook Press, New York.

MONE, 2002. National Education at the Beginning of 2002. MEB Yayınevi, Ankara.

OECD, 2005a. Education at a Glance: OECD Indicators 2005. OECD Publications, Paris, France.

OECD, 2005b. Teachers Matter: Attracting. Developing, and Retaining Effective Teachers. OECD Publications, Paris, France.

Sakaoğlu, N., 2003. Osmanlı'dan Günümüze Eğitim Tarihi. Bilgi Üniversitesi Yayınları, İstanbul.

Sands, M.K., Özçelik, D.A., 1998. Work in Schools: Secondary. YÖK, Ankara. 
State Institute of Statistics. Okur-yazar Olmayan ve Okur-yazar Oranı: 1935-2000. [On-line]. Available at <http://www.die.gov.tr/ tkba/English_TKBA/t098.xls >. Access date: October 142005.

Şimşek, H., Yıldırım, A., 2001. The reform of pre-service teacher education in Turkey. In: Sultana, R. (Ed.), Challenge and Change in the Euro-Mediterranean Region: Case Studies in Educational Innovation. Peter Lang Inc, New York.
UNDP, Human Development Reports: Country Tables [On-line] Available at $\langle$ http://hdr.undp.org/statistics/data/countries.cfm $\rangle$. Access date:October 14, 2005.

World Bank, 2005. Turkey-education Sector Study: Sustainable Pathways to an Effective, Equitable, and Efficient Education System for Pre-school Through Secondary School Education. The World Bank Publications, Washington, DC. 